\title{
To the study of vegetation cover in the vicinities of Pirekyashkyul mud volcano (Azerbaijan)
}

\section{Shabnam Q. Isayeva \\ Institute of Botany, Azerbaijan National Academy of Sciences, Badamdar 40, Baku, AZ1004, Azerbaijan}

\begin{abstract}
The vegetation cover of the mud volcanoes of Azerbaijan is still unexplored. In this article we present the results for comprehensive floristic and geobotanical investigation. We identified and analyzed the plant species composition of the Pirekyashkyul mud volcano, located in the Gobustan botanical and geographical area. It has been established that the vegetation cover of the volcano is characterized by low floristic diversity, which consist of 18 species of vascular plants from 16 genera and 7 families. By the method of phytosociological profiling, patterns of distribution of plant communities and groups in the territory adjacent to the mud volcano Pirekyashkyul were revealed. The number of species in phytocoenosis and their total projective cover increase from the periphery to the middle part, at the center it decreases sharply to one species. A pronounced mosaic of the vegetation cover associated with temperature gradient, wind direction, substrate moisture regime, and sides of the horizon is observed. The vegetation cover of the mud volcanos is specific, but there is no sharp difference from the vegetation of the territory.
\end{abstract}

Key Words: phytosociological profiling, plant communities, Gobustan, species composition, ephemera, eruptive center

\section{INTRODUCTION}

Mud volcanoes are geological structures formed as a result of the penetration of clay materials on the surface of the Earth or the seabed [Dimitrov, 2002a]. A sufficient amount of water and gas are combined, making clay materials semi-liquid, and also pushing them up through the cracks of the crust for the expiration of the muddy mass to the surface. The composition of the gases emitted by mud volcanoes varies from region to region; in most of them methane predominates, which usually accounts for more than $85 \%$ of the total gas composition [Judd, 2005]. It has been noted that in some oil-rich provinces, such as the South Caspian basin, gases with higher hydrocarbon content are present [Dimitrov, 2002b]. The

Accepted for publication: 5 November 2019

${ }^{1}$ E-mail: isayeva.shabnam@outlook.com most common gas besides methane is usually carbon dioxide. Mud volcanoes have a direct and indirect effect on the vegetation cover. Direct effects include the burial of plants under streams of breeding breccia and mechanical damage of plants by gas emissions during eruptions. Indirect impact is expressed by a change in the chemical property of the substrate, moisture, surface air composition due to the emission of gases from eruptive centers and cracks in the substrate.

Volcanic eruptions determine the environment against which plant communities will exist [Manko, Sidelnikov, 1989; Neshataeva, 2009]. The power of the eruption and the volume of the ejected substrate determine the nature of the formation and characteristics of the microrelief and microhabitats. The influence of mud volcanoes, as well as igneous on vegetation is expressed in the appearance of dynamic series of plant communities - from pioneer to climax, i.e. initiating the process of ecological succession [Grishin et al., 1996; Korznikov 2015]. There are many global studies of mud volcanoes that reveal aspects of their origin, mechanisms of formation and paleoactivity worldwide [Ranjbaran, Sotohian, 2015].

The territory of Azerbaijan is a unique region of mud volcanism [Aliyev, Guliyev, Belov, 2010; Planke et al., 2003]. Out of 800 mud volcanoes existing in the world about 400 are located within the South Caspian oil and gas basin and more than 300 of them are located on-shore of the East Azerbaijan and adjacent water area of the Caspian Sea. All forms of mud volcanic manifestations (active, buried, underwater, island and oil) can be observed here.

By the number of volcanoes, their diversity and intensity, Azerbaijan takes the first place in the world [Khain, Khalilov, 2009]. The most famous mud volcanoes are in Gobustan. In recent years, volcanoes have experienced significant recreational pressures associated with tourism, population and climate change.

The mud volcano Pirekyashkyul is located 39-41 $\mathrm{km}$ west of Baku, 7-9 km from Bayanat Mountain (049 ○ 26 ' 5.22 ' 'east; $40^{\circ} 28^{\prime} 49.3$ ' 'north). This is one of the unique natural complexes, which is protected by the state and is a part of the State Nature Reserve in the Absheron peninsula. To date, researchers have studied the geochemical features and balneological properties 
of volcanic mud. As a result, it was introduced into the medical practice of more than 15 relevant organizations of Azerbaijan [Aliyev, Guliyev, 2015].

However, despite the geological and geographical studies of the mud volcano Pirekyashkyul, its vegetation cover has not yet been studied. In this regard, the aim of the investigation was to study the flora, as well as plant communities and plant aggregation of the mud volcano Pirekyashkyul.

\section{MATERIAL AND METHODS}

Description of the territory. According to the botanical and geographical zoning of Azerbaijan, the studied territory belongs to the Gobustan massif, which occupies the south-eastern extremity of the foothills of the Main Caucasus Range (eastern part of Azerbaijan). It has the shape of an irregular polygon with an area of 800 thousand ha. The high-altitude zones of the massif are within $700 \mathrm{~m}$ a. s. 1 . This region belongs to the piedmont low-mountain type and, in tectonic-geomorphological terms, is a part of the vast meganticlinorium of the Great Caucasus. Pirekyashkyul mud volcano is located on the Eocene crumpled rocks and confined to the tectonic dislocation of Gultepe anticline [Aliyev, Guliev, 2015]. Morphologically represented by three groups of hills and griffins located on both sides of Baku-Shamakhi route (Fig. 1), the absolute height is $321 \mathrm{~m}$, the relative height is $55 \mathrm{~m}$. Oil emitted gryphons can be seen within one of the group. An area covered with breccias is 240 by $100 \mathrm{~m}$.

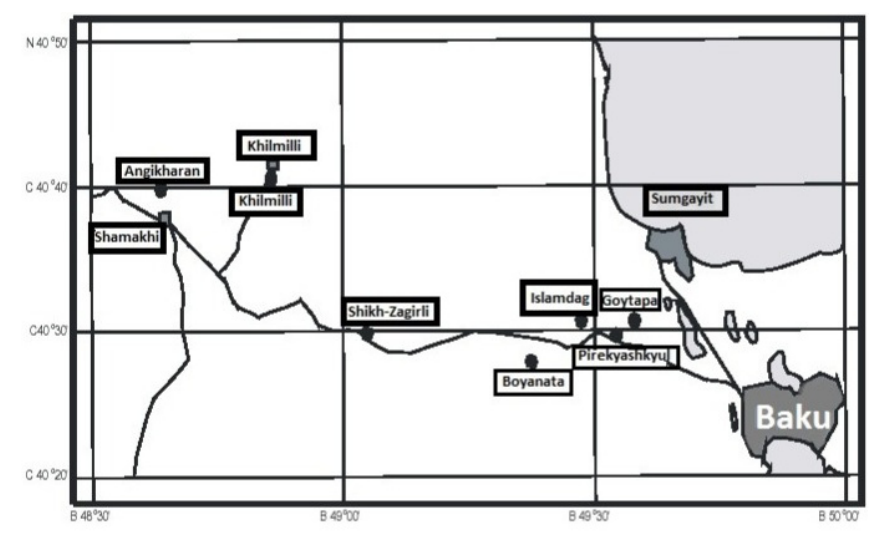

Figure 1. Site localization map.

Grey-brown, salty soils can be found in the lowest parts of Gobustan [Mamedaliev, 1963]. Crusts of gypsum and salt on loamy soils are typical at altitudes between the Caspian Sea and $150 \mathrm{~m}$ a.s.l. With rising altitude, they give way to raw or brown soils with lower salt content, interspersed with Solontschaks. Chestnut and light chestnut soils can be found in the western part of Gobustan [Schmidt, Sebastian, 2009].

The territory of Gobustan ranges from the shores of the Caspian Sea to Mount Gijaki, the highest point in eastern part the Great Caucasus. Peculiarities of Gobustan landscape are the rocks of lime and sandstone in the middle territory of the district, and mud volcanoes, which are located in the east part of Gobustan.

Semi-desert climate is specific to Gobustan. Winters are mild, and summers are hot in there. Rain periods are early spring and late autumn. The annual precipitation is $250 \mathrm{~mm}$. The western part of Gobustan is more precipitated in autumn and spring than eastern part of Gobustan since Kura lowlands covers the western part. The highest mean temperature is observed in July (32 ${ }^{\circ} \mathrm{C}$ ) and the lowest mean temperature occurs in January $\left(-1.6{ }^{\circ} \mathrm{C}\right)$ [Schmidt, Sebastian, 2009]. Average annual precipitation $400-600 \mathrm{~mm}$, number of solar radiance 2200-2400 hours [Mamedov, Khalilov, Mamedova, 2010].

The study was of a monitoring nature. Route-reconnaissance studies were carried out in April-September 2018 by the linear transect method, crossing a mud volcano along a high-altitude, temperature, wind, and soil gradient (from the periphery to the center, from the center to the periphery, from south to north). On the laid solid linear transect with a total length of $97 \mathrm{~m}$, accounting plots of $1 \mathrm{~m}^{2}$ in size were laid, which were located in a row, without intervals between them. At the sites, the species composition of vascular plants was recorded, the projective cover of each species, as well as the area of exposed soil were determined (Figs. 2, 3).

The instrumental surveys of the vegetation cover were carried out for studying the spatial distribution of plant communities, on 3-high sections of the mud volcano Pirekyashkyul (No. 1-foot, No. 2-the middle part, No. 3- the eruptive center), as well as the changes of plant communities and groups were described.

Communities were determined by a dominantdeterminant principle. Life forms were determined by ecological and morphological characteristics, according to I.G. Serebryakov [1964] and A.G. Ramensky [1937]. Ecological analysis of plants was determined according to A.P. Shennikov [1964]. The plant groups were selected considering the depth of the root systems as per S.A. Bedarev [1968]. The abundance and coverage (in \%) of species were carried out as described by Braun-Blanquet system [1964]. The coordinates of the test plots, transects and altitude were determined using the GPS Garmin III Plus. 


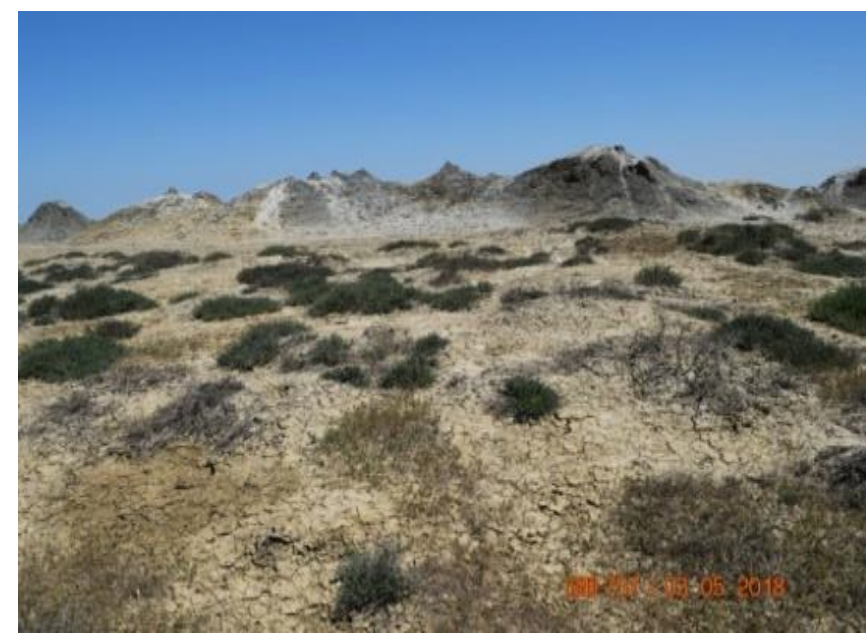

Figure 2. Terrain of the study area.

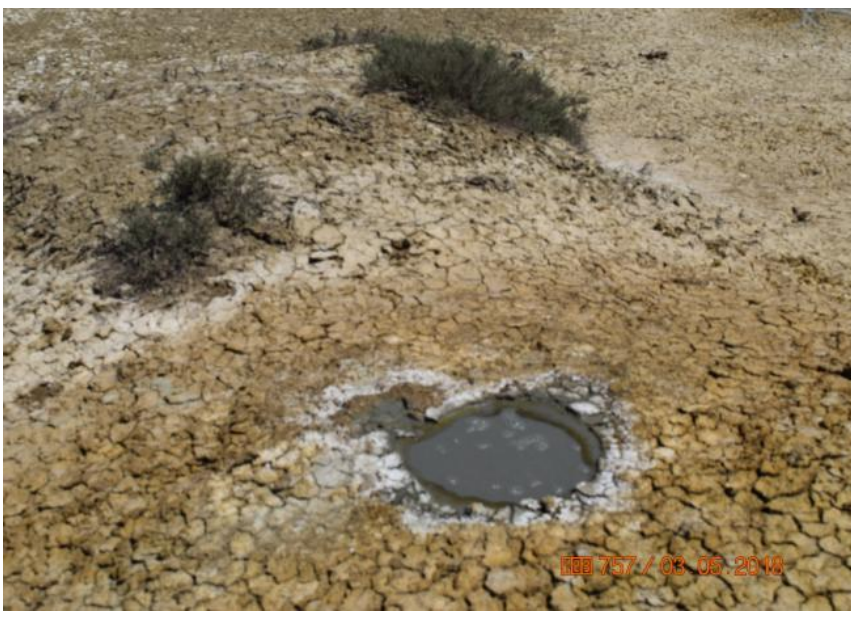

Figure 3. The eruptive center of mud volcano.

\section{RESULTS AND DISCUSSION}

The study found that the Pirekyashkul mud volcano flora has a low species composition (18 species), which is associated with harsh plant development conditions. Identified species belong to 7 families: Asteraceae Dumort., Chenopodiaceae Vent., Geraniaceae Juss., Limoniaceae Ser., Poaceae Barnhart, Plantaginaceae Lindl., Scrophulariaceae Juss. and 16 genera: Anthemis L., Carduus L., Filago L., Scorzonera L., Tragopogon L., Climacoptera (Bieb.) Botsch., Petrosimonia Bge., Salsola L., Suaeda Forssk. ex Scop., Erodium L'Herit., Psylliostachys (Jaub. et Spach.) Nevski, Anisantha Panz., Bromus L., Eremopyrum J.et Sp., Plantago L., Veronica L.

The largest number of species is characterized by the family Chenopodiaceae Vent. - 6 species $(33 \%$ of the total number of species) and Asteraceae Dumort.-5 species $(28 \%$ of the total number of species). The Poaceae Barnhart includes 3 species (17\% of the total number of species), the remaining families - 1 species each (5\% of the total number of species) (Fig. 4). The species composition of the mud volcano lacks endemic taxa.

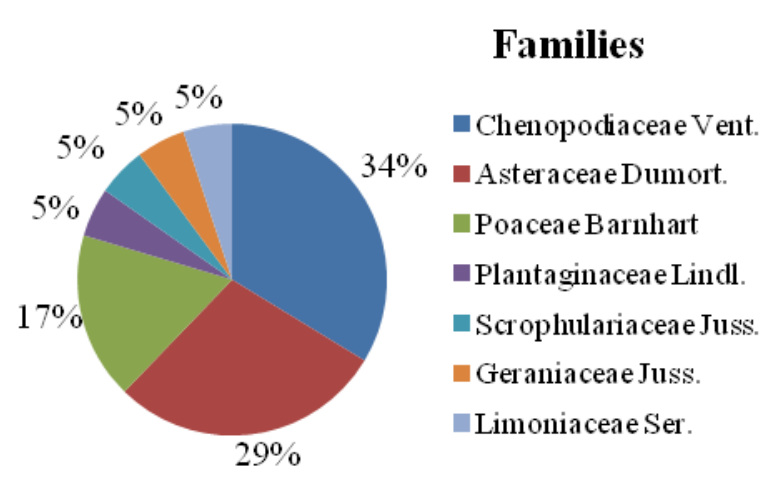

Figure 4. The number of species (\%) of plant families of the Pirekyashkyul mud volcano.

The results of the analysis of life forms (Tab. 1) showed that annual species of herbaceous plants account for 12 species (67\%), perennial plants - 2 species $(11 \%)$, shrubs are represented by 4 species $(22 \%)$. The spectrum of ecological groups in the vegetation cover of a mud volcano is dominated by plants of the halomesoxerophytic ( 5 species, $28 \%$ ) and haloxerophytic ( 5 species, $28 \%$ ) ecotype.

Depending on the way they take up moisture most desert plants may be classified as ombrophytes, trichohydrophytes or phreatophytes. According to the type of root system occurrence, ombrophytes, a group of plants whose root system is located in the surface layer of the soil and take up water directly from precipitation, predominate - 12 species (67\%), phreatophytes, thick roots that tap directly into groundwater, account 4 species $(22 \%)$ and trichohydrophytes, have complex root systems that penetrate fairly deeply into the soil (2-3 $\mathrm{m}$ and more) and take up groundwater by means of capillary action, account for 2 species $(11 \%)$.

The plant communities of the mud volcano Pirekyashkyul do not contrast with the background semi-desert vegetation of the general landscape of the territory under study. However, the distribution of plant communities around the ejected mud breccia material of the volcano is uneven (Tab. 2).

On the laid transect, five sites with communities and characteristic of them were identified, the description of which is given in Figure 5 (profile):

Site No. 1: The northern and northeastern parts of the foot of mud volcano, are occupied by annual saltwort communities with Petrosimonia brachiata and 


\section{PLANT \& FUNGAL RESEARCH}

Table 1. List of species distributed in the area adjacent to the Pirekyashkyul volcano (IV.2018)Ş

\begin{tabular}{|c|c|c|c|c|c|c|}
\hline Name of the species & Life form & Ecotype & $\begin{array}{c}\text { Abundance } \\
\text { (in points) }\end{array}$ & Tier & Phenophase & Root system \\
\hline \multicolumn{7}{|c|}{ Asteraceae Dumort. } \\
\hline $\begin{array}{l}\text { Anthemis candidissima } \\
\text { Willd. ex Spreng. }\end{array}$ & annual & xerophyte & 4 & 2 & blossom & ombrophyte \\
\hline $\begin{array}{c}\text { Carduus cinereus } \\
\text { M. Bieb. }\end{array}$ & annual & mesoxerophyte & 2 & 2 & blossom & ombrophyte \\
\hline $\begin{array}{l}\text { Filago germanica } \\
\text { (L.) Huds. }\end{array}$ & annual & xerophyte & $3-4$ & 1 & bud & ombrophyte \\
\hline Scorzonera laciniata L. & biennial & mesoxerophyte & $1-2$ & 2 & blossom & ombrophyte \\
\hline $\begin{array}{c}\text { Tragopogon pusillus } \\
\text { M. Bieb. }\end{array}$ & perennial & xeromesophyte & $1-2$ & 2 & blossom & ombrophyte \\
\hline \multicolumn{7}{|c|}{ Chenopodiaceae Vent. } \\
\hline $\begin{array}{l}\text { Climacoptera crassa } \\
\text { (Bieb.) Botsch. }\end{array}$ & annual & haloxerophyte & $3-4$ & 2 & vegetation & trichohydrophyte \\
\hline $\begin{array}{l}\text { Petrosimonia brachiata } \\
\text { (Pall.) Bunge }\end{array}$ & annual & haloxerophyte & $4-5$ & 1 & vegetation & trichohydrophyte \\
\hline $\begin{array}{l}\text { Salsola dendroides } \\
\text { Pall. }\end{array}$ & subshrub & halomesoxerophyte & 4 & 1 & vegetation & phreatophyte \\
\hline $\begin{array}{l}\text { Salsola nodulosa } \\
\text { (Moq.) Iljin }\end{array}$ & shrub & haloxerophyte & 4 & 2 & vegetation & phreatophyte \\
\hline $\begin{array}{c}\text { Suaeda microphylla } \\
\text { Pall. }\end{array}$ & shrub & haloxerophyte & $2-3$ & 1 & vegetation & phreatophyte \\
\hline $\begin{array}{l}\text { Suaeda dendroides } \\
\text { (C.A. Mey.) Moq. }\end{array}$ & shrub & haloxerophyte & $4-5$ & 3 & vegetation & phreatophyte \\
\hline \multicolumn{7}{|c|}{ Geraniaceae Juss. } \\
\hline $\begin{array}{l}\text { Erodium cicutarium } \\
\text { (L.) L' He'r. }\end{array}$ & annual & halomesoxerophyte & $3-4$ & 2 & blossom & ombrophyte \\
\hline \multicolumn{7}{|c|}{ Limoniaceae Ser. } \\
\hline $\begin{array}{l}\text { Psylliostachys spicata } \\
\text { (Willd.) Nevski }\end{array}$ & annual & halomesoxerophyte & $2-3$ & 2 & blossom & ombrophyte \\
\hline \multicolumn{7}{|c|}{ Poaceae Barnhart } \\
\hline $\begin{array}{l}\text { Anisantha rubens } \\
\text { (L.) Nevski }\end{array}$ & annual & mesoxerophyte & $3-4$ & 2 & vegetation & ombrophyte \\
\hline Bromus lanceolatus Roth. & annual & halomesoxerophyte & $2-3$ & 2 & vegetation & ombrophyte \\
\hline $\begin{array}{c}\text { Eremopyrum orientale (L.) } \\
\text { Jaub. \& Spach } \\
\end{array}$ & annual & mesoxerophyte & $2-3$ & 2 & vegetation & ombrophyte \\
\hline \multicolumn{7}{|c|}{ Plantaginaceae Lindl. } \\
\hline Plantago notata Lag. & annual & halomesoxerophyte & 2 & 1 & blossom & ombrophyte \\
\hline \multicolumn{7}{|c|}{ Scrophulariaceae Juss. } \\
\hline Veronica polita Fr. & annual & xerophyte & 2 & 1 & blossom & ombrophyte \\
\hline
\end{tabular}

Climacoptera crassa which forming two communities Petrosimonia brachiata+Ephemerae and Climacoptera crassa+Ephemerae. The species composition of both communities is extremely poor, consists mainly of the most xerophytic salt-tolerant grasses. Three to five species are registered in these communities: Anisantha rubens and Eremopurum orientale with abundance 4 points and 3 points respectively (coverage from 30 to $40 \%)$.
Site No. 2: The northern and northwestern parts of the mud volcano, occupied by saltwort-ephemeral communities, with dominated by Salsola nodulosa and Salsola dendroides, which forming community Salsola nodulosa + Salsola dendroides+Ephemerae. The species composition in comparison with previous section is more diverse and has 7-9 species. The representatives of forbs, such as Tragopogon pusillus, Scorzonera laciniata appear in the synusia of ephemera with low 
Table 2. Plant communities of the volcano Pirekyashkyul.

\begin{tabular}{|c|c|c|c|c|c|}
\hline \multirow[b]{2}{*}{$\begin{array}{l}\text { Projective cover and } \\
\text { species composition }\end{array}$} & \multicolumn{5}{|c|}{ Communities } \\
\hline & $\begin{array}{c}\text { Petrosimonia } \\
\text { brachiata }+ \\
\text { Ephemerae }\end{array}$ & $\begin{array}{c}\text { Climacoptera } \\
\text { crassa }+ \\
\text { Ephemerae }\end{array}$ & $\begin{array}{l}\text { Salsola nodulosa }+ \\
\text { Salsola dendroides } \\
\quad+\text { Ephemerae }\end{array}$ & $\begin{array}{c}\text { Suaeda } \\
\text { microphylla+ } \\
\text { Suaeda } \\
\text { dendroides }+ \\
\text { Ephemerae } \\
\end{array}$ & Ephemerae \\
\hline $\begin{array}{l}\text { Coverage (in \%) of } \\
\text { community }\end{array}$ & 30 & 40 & 45 & 60 & 40 \\
\hline Name of species & \multicolumn{5}{|c|}{ Abundance of species (Braun-Blanquet) } \\
\hline $\begin{array}{l}\text { Anthemis candidissima } \\
\text { Willd. ex Spreng. }\end{array}$ & - & 2 & - & 1 & 1 \\
\hline $\begin{array}{l}\text { Carduus cinereus } \\
\text { M. Bieb. }\end{array}$ & - & - & - & 1 & 2 \\
\hline $\begin{array}{l}\text { Filago germanica } \\
\text { (L.) Huds. }\end{array}$ & 1 & - & - & 2 & 2 \\
\hline Scorzonera laciniata L. & - & - & 2 & 2 & 1 \\
\hline $\begin{array}{l}\text { Tragopogon pusillus } \\
\text { M. Bieb. }\end{array}$ & - & - & 2 & 2 & 2 \\
\hline $\begin{array}{l}\text { Climacoptera crassa } \\
\text { (Bieb.) Botsch. }\end{array}$ & 1 & 4 & - & - & - \\
\hline $\begin{array}{l}\text { Petrosimonia brachiata } \\
\text { (Pall.) Bunge }\end{array}$ & $4-5$ & - & - & - & - \\
\hline Salsola dendroides Pall. & - & - & 4 & 2 & - \\
\hline $\begin{array}{l}\text { Salsola nodulosa (Moq.) } \\
\text { Iljin }\end{array}$ & - & - & 4 & 1 & - \\
\hline Suaeda microphylla Pall. & - & - & - & 5 & - \\
\hline $\begin{array}{l}\text { Suaeda dendroides(C.A. } \\
\text { Mey.) Moq. }\end{array}$ & - & - & - & 4 & - \\
\hline $\begin{array}{l}\text { Erodium cicutarium(L.) } \\
\text { L' He'r. }\end{array}$ & - & - & 2 & 3 & 2 \\
\hline $\begin{array}{l}\text { Psylliostachys spicata } \\
\text { (Willd.) Nevski }\end{array}$ & - & - & - & 2 & 2 \\
\hline $\begin{array}{l}\text { Anisantha rubens (L.) } \\
\text { Nevski }\end{array}$ & $2-3$ & 2 & 3 & 1 & 3 \\
\hline $\begin{array}{l}\text { Bromus lanceolatus } \\
\text { Roth. }\end{array}$ & - & - & 1 & 2 & 2 \\
\hline $\begin{array}{l}\text { Eremopyrum orientale } \\
\text { (L.) Jaub. \& Spach }\end{array}$ & 3 & 3 & 2 & 2 & 3 \\
\hline Plantago notata Lag. & - & - & - & 2 & 1 \\
\hline Veronica polita Fr. & - & 2 & 2 & 2 & 2 \\
\hline Species richness & 5 & 5 & 9 & 16 & 12 \\
\hline
\end{tabular}

abundance. Projective cover due to the aerial part of saltwort and ephemera rises to $45 \%$ in some places by $50 \%$.

Site No. 3: The eruptive center of mud volcano with a diameter of $5-8 \mathrm{~m}$. This part is characterized by the absence of vegetation, which is associated with mud, mudclay saline volcanic emissions that prevent the establishment of plants on this site. In the south site, only separate specimens of generative and regenerative species of Suaeda microphylla are observed.

Site No. 4: The southern, southeastern and southwestern of mud volcano. On this site registred communities Suaeda microphylla+Suaeda dendroides +Ephemerae with dominance by Suaeda microphylla and Suaeda dendroides. From other saltwort with low abundance Salsola nodulosa is noted here. This site compared with sites No. 1, 2, 3 has a higher projective cover $60 \%$ (in some places 70\% ) and species diversity (Veronica polita, Psylliostachys spicata, Anisantha rubens, Erodium cicutarium etc.).

Site No. 5: The southern and southeastern parts of the foot of mud volcano, are represented by the ephemeral 


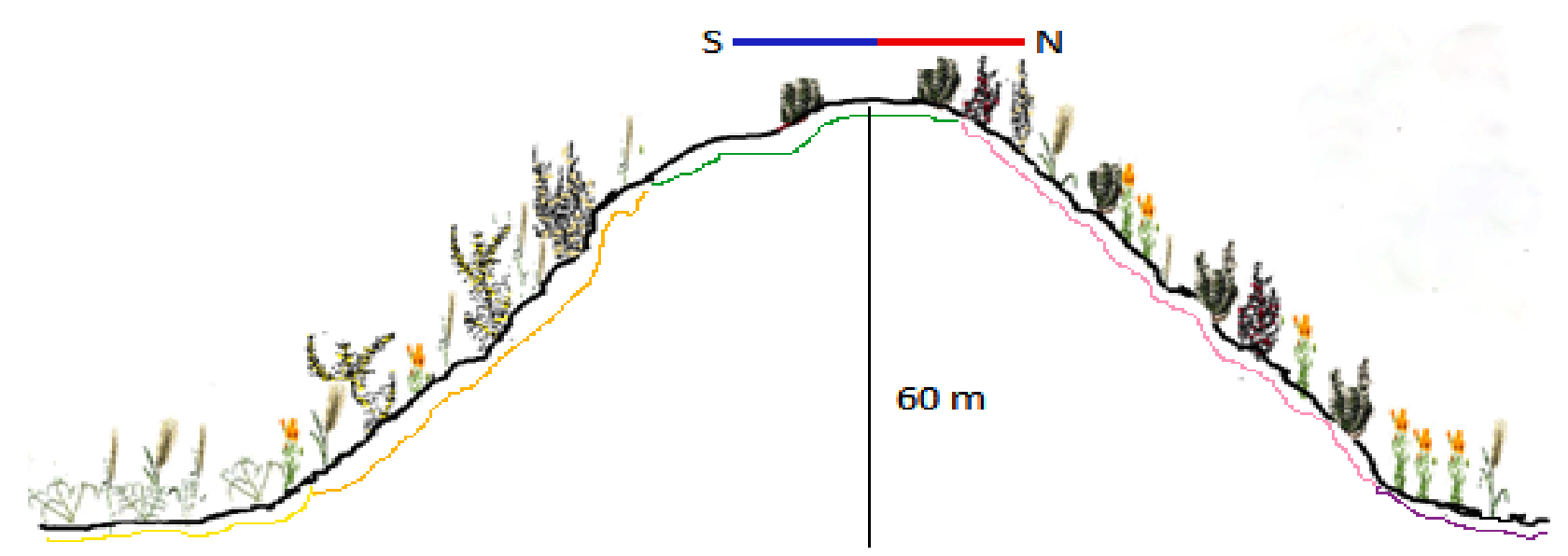

Figure 5. Microprofile of the Pirekyashkyul mud volcano:

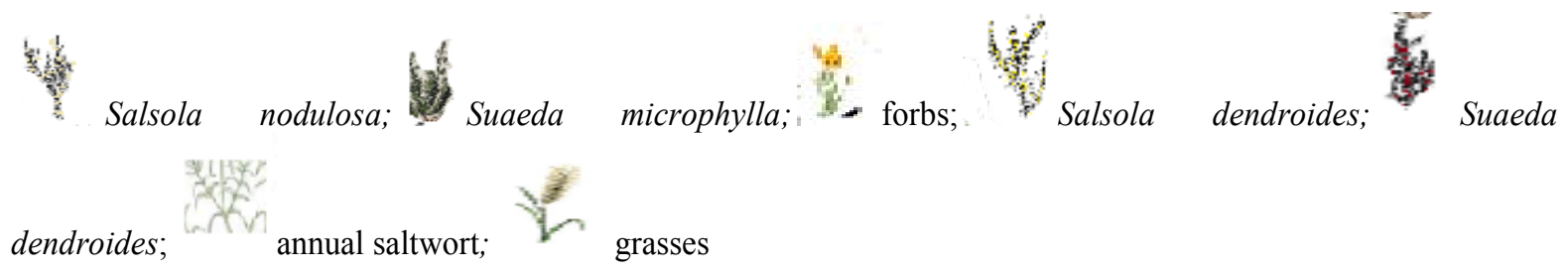

community (Ephemerae) with the participation of grasses and forbs, among which Anisantha rubens, Bromus lanceolatus, Eremopyrum orientale etc.). Projective cover is $40 \%$.

Thus, five vegetation communities were identified in the mud volcano Perekishkyul - two annual saltwort (Petrosimonia brachiata+Ephemerae; Climacoptera crassa+Ephemerae), two saltworts-ephemeral (Salsola nodulosa+Salsola dendroides+Ephemerae; Suaeda dendroides + Suaeda microphylla+Ephemerae and one with the participation of ephemeral (Ephemerae). The mosaic distribution of these communities, in our opinion, is associated with the temperature gradient, moisture and soil conditions of the substrate, which requires additional detailed studies.

The growth of perennial and annual xerogalophytes indicates sulfate salinization of the volcano substrates. Annual saltwort community formed by Salsola dendroides and Salsola nodulosa concentrated in the southern lower part, as well as relatively young community formed by $S$. microphylla and $S$. dendroides in the northern part are indicators of secondary salinization of mature saltwort community.

Sinusia of ephemera is present throughout the volcano. However, in its southern part the ephemera are represented by more xerophytic grasses, and in the northern part by more mesophilic forbs conditioned by the uneven temperature regime and the drying effect of the wind. The high determining effect of the temperature regime, as well as the modes of moisture and salinity of the substrate affect species diversity and mosaic vegetation of the territory of the mud volcano.

\section{CONCLUSION}

The vegetation cover of the territory of the studied mud volcano is represented by desert vegetation, in which we identified five communities. It has been established that the abundance and diversity of the vegetation cover increases with distance from the eruptive center, which corresponds to the gradient of water and temperature.

The studies also describe the microbelt structure of the vegetation cover in five key high-altitude areas in detail. The flora of the mud volcano Pirekyashkyul contains 18 species of vascular plants, from 7 families and 16 genera. The largest number of species is represented by the families Chenopodiaceae and Asteraceae (6 and 5 species, respectively). The poor flora composition could be explained by the activity of the mud volcano and difficult environmental conditions.

\section{REFERENCES}

Aliyev Ad.A., Gasanov A.G., Kabulova A.Y., Abbasly A.A. (1989) Gryazevyye vulkany i seysmichnost' Shemakhino-Gobustanskogo rayona. V kn.: "Materialy yubileynoy sessii, posvyashchennoy 50-letiyu Instituta geologii AN Azerb. SSR". Baku: Elm, 215217.

Aliyev Ad.A., Guliyev I.S., Dadashe F.G., Rakhmanov 
R.R. (2015) “Atlas gryazevykh vulkanov mira”, 47151.

Bayramova Sh.Sh. (2018) Palinostratigrafiya i usloviya formirovaniya maykopskoy svity ShamakhaGobustanskoy oblasti Azerbaydzhana. Izdatel'stvo. Baku: Nafta-Press, 9 s.

Bedarev S.A. (1968) Transkriptsiya i raskhod vody rastushchey aridnoy zony Kazakhstana. Leningrad: Gidrometeoizdat, 34-228. (In Russian)

Aliyev Ad.A., Guliyev I.S., Belov I.S. (2002) Catalogue of recorded eruptions of mud volcanoes of Azerbaijan (for period of years 1810-2001) Baku: Nafta Press, $88 \mathrm{p}$.

Barkalov V.Yu., Kozhevnikov A.E., Smirnov A.A., Tsarenko N.A. (2006) Features of the vegetation cover of the Pugachev Mud Volcano (South Sakhalin). Komarov Readings, 52: 127-147.

Del Moral R., Lacher I.L. (2005) Vegetation patterns 25 years after the eruption of Mount St. Helens, Washington, USA. Am. J. Bot., 92 (12): 1948-1956.

Dimitrov L. (2002 a) Mud volcanoes - the most important pathway for degassing deeply buried sediments, Earth-Sci. Rev., 59: 49-76.

Dimitrov L. (2002 b) Mud volcanoes - a sizeable source of atmospheric methane. VII International conference on gas in marine sediments, Baku, Azerbaijan, Abstracts 33.

Ershov V.V., Mel'nikov O.A. (2007) Unusual eruption of themain Pugachevo gas-water-lithoclastic (mud) volcano during the winter of 2005. Russ. J. Pac. Geol., 1 (4): 366-370.

Khain V.E., Khalilov E.N. (2008) Spatial-temporal patterns of seismic and volcanic activity. Bourgas, Bulgaria: SWB, $304 \mathrm{c}$.

Khain V.E., Khalilov E.N. (2009) Cyclicality of geodynamic processes: Its possible nature. Moscow: Scientific World, $520 \mathrm{p}$.

Korzhenevsky V.V., Klyukin A.A. (1991) Vegetation description of mud volcanoes of Crimea. Feddes Repertorium, 102(1-2): 137-150.

Mamedov G.Sh., Khalilov M.Y., Mamedova S.Z. (2010) Ecological Atlas. Baku Cartographic Factory, 28-30.

Planke S., Svensen H., Hovland M., Banks D.A., Jamtvei B. (2003) Mud and fluid migration in active mud volcanoes in Azerbaijan. Geo-Mar Lett, 23: 258-268.

Ranjbaran M., Sotohian F. (2015) Environmental impact and sedimentary structures of mud volcanoes in southeast of the Caspian Sea basin, Golestan Province, Iran.CJES, 13(4): 391-405.
Schmidt S. (2009) Potential analysis for further nature conservation in Azerbaijan: A Spatial and Political Investment Strategy. Greifswald: Geozon Science Media., 73-75.

Shennikov A.P. (1964) Introduction to Geobotany L.: Publishing House. Leningrad.Univ., 447 s.

\section{Pirəkəşkül palçıq vulkan ətrafı bitki örtüyünün öyronilməsi}

\section{Şəbnəm Q. İsayeva}

AMEA Botanika Institutu, Badamdar şossesi 40, Bakl, AZ1004, Azərbaycan

Azərbaycanın palçıq vulkanlarının bitki örtüyü hələ də öyrənilməyib. Bu məqalədə hərtərəfli floristik və geobotaniki araşdırmaların nəticələrini təqdim edirik. Qobustan botaniki və coğrafi ərazisində yerləşən Pirəkəşkül palçıq vulkanının bitki növlərinin tərkibi müəyyənləşdirilərək təhlil edilmişdir. Vulkanın bitki örtüyü 16 cins və 7 fəsiləyə aid 18 növdən ibarət olan floristik müxtəliflik ilə xarakterizə olunur. Geobotaniki profilləmə üsulu ilə Pirəkəşkül palçıq vulkanına bitişik ərazidə bitki birliklərinin və qruplarının yayılma qanunauyğunluqları aşkar edilmişdir. Fitosenozda olan növlərin sayı və onların ümumi proyektiv örtüyü periferiyadan orta hissəyə qədər artır, mərkəzdə bir növə qədər kəskin şəkildə azalır. Temperatur qradiyenti, küləyin istiqaməti, substratın rütubət rejimi və üfüqün cəhətləri ilə əlaqəli bitki örtüyünün aydın mozaikası müşahidə olunur. Palçıq vulkanının bitki örtüyü spesifikdir, lakin ərazinin bitki örtüyündən kəskin fərqlənmir. Açar sözlor: fitososioloji profillaşdirma, bitki icmaları, Qobustan, növ tarkibi, efemerlar, püskürma markazi

\section{К изучению растительного покрова в окрестностях грязевого вулкана Перекишкюль (Азербайджан)}

\section{Шабнам Г. Исаева}

Институт Ботаники НАНА, Бадамдар 40, Баку, АZ1004,Азербайджан

Растительный покров грязевых вулканов Азербайджана до настоящего времени оставался не изученной областью ботаники. В этой статье мы представляем результаты всестороннего флористического и геоботанического исследования. Выявлен и проанализирован видовой состав растений грязевого вулкана Перекишкюль, расположенного в Гобустанском ботанико-географическом районе. 


\section{PLANT \& FUNGAL RESEARCH}

Установлено, что растительный покров грязевого вулкана характеризуется низким флористическим разнообразием, состоящим из 18 видов сосудистых растений из 16 родов и 7 семейств. Методом геоботанического профилирования выявлены закономерности распространения растительных сообществ и групп на территории, прилегающей к грязевому вулкану Перекишкюль. Количество видов при фитоценозе и их общее проективное покрытие увеличивается от периферии к средней части, в центре рез- ко уменьшается до одного вида. Наблюдается ярко выраженная мозаичность растительного покрова, связанная с градиентом температуры, направлением ветра, режимом влажности субстрата и сторонами горизонта. Растительный покров грязевого вулкана специфичен, однако резкого отличия от растительности фоновых местообитаний не наблюдается.

Ключевые слова: фитосочиологическое профилирование, растительные сообщества, Гобустан, видовой состав, эфемеры, эруптивный центр 